This document is the accepted manuscript version of the following article:

Lutter, S., Pfister, S., Giljum, S., wieland, H., \& Mute1, C. (2016). Spatially explicit assessment of water embodied in European trade: a product-1eve1 multiregional input-output analysis. Global Environmental Change, 38, 171-182.

https://doi.org/10.1016/j.gloenvcha.2016.03.001

\title{
Spatially explicit assessment of water embodied in European trade: a product-level multi-regional input-output analysis
}

\begin{abstract}
Responsible water management in an era of globalised supply chains needs to consider both local and regional water balances and international trade. In this paper, we assess the water footprints of total final demand in the EU-27 at a very detailed product level and spatial scale an important step towards informed water policy. We apply the multi-regional input-output (MRIO) model EXIOBASE, including water data, to track the distribution of water use along product supply chains within and across countries. This enables the first spatially-explicit MRIO analysis of water embodied in Europe's external trade for almost 11,000 watersheds world-wide, tracing indirect ("virtual") water consumption in one country back to those watersheds where the water was actually extracted. We show that the EU-27 indirectly imports large quantities of blue and green water via international trade of products, most notably processed crop products, and these imports far exceed the water used from domestic sources. The Indus, Danube and Mississippi watersheds are the largest individual contributors to the EU-27's final water consumption, which causes large environmental impacts due to water scarcity in both the Indus and Mississippi watersheds. We conclude by sketching out policy options to ensure that sustainable water management within and outside European borders is not compromised by European consumption.
\end{abstract}

\section{Key words}

Virtual water, multi-regional input-output (MRIO) analysis, water footprinting, water scarcity, watersheds

\section{Highlights}

1. Disaggregated water multi-regional input-output analysis allows pinpointing water use

induced by final consumption per product and per watershed.

2. The large majority of water use induced by European consumption is sourced outside Europe.

3. The top-3 watersheds world-wide supplying water for EU final demand are the Indus, Danube and Mississippi.

4. Processed crop products dominate virtual water flows embodied in final consumption. 


\section{Introduction}

Water is a renewable resource, but its availability varies in time and space. The current dense web of globalised production and consumption patterns interlinked by international trade places localized stress on water resources in many areas of the globe (Hubacek et al. 2014). Due to growing demand for agricultural and manufactured products, as well as for thermal electricity generation and domestic use, water withdrawals are projected to increase by 55\% through 2050 (UN Water 2014). Hence, in a globalised economy, local water depletion and pollution are often closely tied not only to in situ water use but also to consumption elsewhere on the planet where water is used to produce export products. As a consequence, 'embodied' or 'virtual' water flows around the globe are associated with the traded commodities (Allan 1994; also termed "indirect water flows").

Integrating economic data and environmental data on water use within a consistent accounting framework allows to quantify the potential impact of specific economic sectors as well as relative benefits of mitigation measures also in watersheds far away from final consumption. There are two main approaches to achieve this integration. "Top-down" approaches using multi-regional input-output (MRIO) models start with the overall water appropriation in a specific geographical unit and for the production of a specific sector, and allocate these water volumes to final demand via monetary information on national and international trade (for instance, Tukker and Dietzenbacher 2013). They hence account for direct and indirect resource flows associated with the economic activity of a specific country or region, and allow linking resource use to economic activities along the complete international supply chains of all products and services delivered to final demand (Tukker et al. 2009; Dietzenbacher et al. 2013; Lenzen et al. 2013a; Tukker and Dietzenbacher 2013). These models have been applied already in various studies for a number of environmental issues, including material use (Bruckner et al. 2012; Wiedmann et al. 2013; Giljum et al. 2015) and greenhouse gas emissions (e.g. Peters et al. 2012; Peters et al. 2011; Cranston and Hammond 2012). However, for the case of water only a limited number of studies are available. Some of them were carried out for specific countries like Spain (Cazcarro et al. 2013; Cazcarro et al. 2012; Dietzenbacher and Velázquez 2007), the UK (Yu et al. 2010) or China (Zhang and Anadon 2014); others for regions such as the EU (Feng et al. 2011) or on the global level (Steen-Olsen et al. 2012; Ewing et al. 2012a). One of the most recent contributions is a study by Lenzen et al. (2013b), who incorporate water scarcity into an assessment of global virtual water flows using input-output analysis. However, all the cited MRIO studies were limited to the country level. This failure to consider local water availability and consumption levels can produce incomplete or misleading results, as certain amounts of extracted water can have different impacts in different watersheds within a country, depending on hydrological and ecosystem structures (Pfister et al. 2009).

In contrast, "bottom-up" or "coefficient-based" approaches quantify the water required for specific products, scale these products up to overall quantities needed for production in a country and allocate these water volumes via trade data to countries of final consumption. The most prominent example for the "bottom-up" approach is the "Water Footprint" developed by 
Hoekstra and colleagues (Hoekstra and Chapagain 2007; Hoekstra and Mekonnen 2012). "Bottom-up" approaches have been used to calculated scarcity-adjusted spatially-explicit consumption-based water footprints (Ridoutt and Pfister 2010; Hoekstra et al. 2012). While bottom-up approaches have the advantage of a very high product detail, especially in the area of agricultural products, they lack the full and consistent coverage of global supply chains for higher processed products, which can lead to underestimations of the overall environmental effect (Hubacek and Feng 2016).

In this paper, we therefore follow the "top-down" approach through applying the MRIO database EXIOBASE (Wood et al. 2015; Tukker et al. 2013); currently the MRIO database with the highest product detail available. For the assessment, EXIOBASE was extended with comprehensive data on water withdrawal and consumption taken from the ETH dataset (Pfister and Bayer 2013; Pfister et al. 2011b) and the Water Footprint Network dataset (Mekonnen and Hoekstra 2011a) for agricultural water consumption as well as the WaterGAP model (Flörke et al. 2013) for industrial water consumption. This allows calculating the direct and indirect water consumption for a unprecedented large number of specific products and product groups and link them to the country or region of origin. The available detail of specific products and categories of water consumptions makes the EXIOBASE the most comprehensive water use extended MRIO (W-MRIO) available to date.

Lenzen et al. (2013b) characterized national footprints and trade balances in terms of scarcityweighted water for 187 individual countries. In this paper, we move one important step further by breaking the water use and consumption induced by European final consumption down to the level of 10,936 watersheds world-wide. This level of spatial detail is unique and crucial, as water scarcity problems can vary significantly across watersheds. Hence, the watershed level is the most relevant level for water management - as has been recognised already by the European Union's Water Framework Directive (European Parliament and Council 2000) and by widely used water scarcity assessment methods (e.g. BWSI; Hoekstra et al. 2012; EEA 2014; Pfister et al. 2009).

With this paper we aim at illustrating the analytical capacity of the EXIOBASE W-MRIO model which combines very high levels of product and geographical detail by creating spatial extension matrices to trace the water consumption to watersheds. We use this state of the art model to identify in-depth hot spots of direct and indirect water use, analyse the contribution of various product groups to the total water footprint and assess cross-country patterns in terms of water use and international trade of embodied water, as well as scarcity levels in the source watersheds. We also discuss advantages and shortcomings of the model and available data, as it is the data quality and availability which restricts W-MRIOs in realising their full analytical potential.

\section{Methodology and data}

Calculations presented in this paper were carried out using EXIOBASE version 2.2 (Wood et al. 2015). The EXIOBASE system was developed in several European research projects and is especially suited for environmental applications (Tukker et al. 2013). In EXIOBASE, national IO 
tables were disaggregated to provide a higher detail for industries and products in environmentally-sensitive sectors, including agriculture and food processing. EXIOBASE 2.2 distinguishes 43 countries (representing around 95\% of global GDP) and 5 rest-of-the-world regions and disaggregates a total of 163 industrial sectors and 200 product groups in each country/region (see list of countries and sectors in the supplementary information). The base year of EXIOBASE 2.2 is 2007, thus all analyses in this paper relate to that specific year. A detailed explanation of the construction of EXIOBASE is provided by Wood et al. (2015).

With regard to the overall sector and product disaggregation level, as well as primary resource extraction sectors, EXIOBASE 2.2 is at the research edge of global environmental-economic analyses. It is clear, however, that such a complex modelling system also contains significant sources of uncertainty. A discussion of general advantages and disadvantages of multi-regional input-output analysis, as well as a comparison with "bottom-up" approaches, can be found in the supplementary information.

\subsection{Water extensions (satellite accounts)}

The integration of economic data and data on water appropriation within a single framework allows illustrating the interaction between the economy and the aquatic environment and helps identifying appropriate measures for so-called "hot spots", i.e. sectors with especially high water intensity. In EXIOBASE, the environmental extension "water consumption" is a set of country and sector specific data on water consumption. Following the MRIO logic, the different water consumption quantities are allocated to the specific sectors where the actual consumption is taking place, thus creating a physical satellite account linked to the monetary MRIO database.

When defining and compiling this set of water extensions, the following aspects must be considered (for more detail see Lutter et al. 2014):

(1) Water use vs. water consumption: Water appropriation by economic activities exerts two different types of pressures on the environment. "Water use" accounts for the actual quantities of fresh water extraction where water is pumped out of e.g. a groundwater body or diverted from a river or lake. Water which is used can be returned to the same water body, although it may be shifted in time or location, and its quality may be changed. "Water consumption" accounts for the share of the extracted water which is lost for the ecosystem, either by incorporation into a product or lost through physical processes such as evapotranspiration.. In the literature, "water consumption" (extraction minus return flows) is also called "consumptive use" (EEA 2014; Pfister et al. 2009).

(2) Geographical and temporal disaggregation: The availability and use of water varies according to factors such as precipitation and temperature. Depending on the data availability, water accounts can be differentiated at various geographical levels, including administrative regions, river basins, and accounting catchments at sub-national level. Temporal aspects could be addressed by monthly water consumption estimates and seasonal trade patterns.

(3) Sectoral disaggregation: Water requirements vary significantly between different economic sectors. On the global level, agriculture is the largest water user, but the electricity sector also 
plays a key role in water use, especially in Europe. A high level of detail in sectoral disaggregation is needed to allocate water appropriation to the responsible economic activity.

Taking all three of these aspects into account would deliver the most detailed set of water extensions. However, despite the global importance of water resources, data availability and quality is strikingly restricted in many countries and sectors. A review of datasets undertaken in the course of setting up the water extensions included in EXIOBASE revealed that data availability has not improved significantly in the last five years. Measured data on water use or consumption is scarce, and modelled data are only available for agriculture and a small number of industrial sectors (Lutter et al. 2013).

The water extensions ("satellite accounts") compiled for the EXIOBASE 2.2 and used for this paper are the following (for further details see the supplementary information and Lutter et al. 2013):

Agriculture: Blue and green water consumption for 13 different crops.

The dataset builds on the data by Pfister et al. (2011b) and Pfister and Bayer (2013). Blue (irrigation) and green (soil moisture) water consumption are calculated for a large number of crops (around $160,>99.9 \%$ of harvested mass), which are then aggregated to the EXIOBASE extensions, which themselves are allocated to 8 product categories.

Livestock husbandry: Blue water consumption for 12 different types of animals

Data on water use and consumption in the livestock husbandry sector (e.g. for drinking water cleaning, etc) were taken from the WaterGAP model which was designed to estimate current and future water withdrawals and consumption of different sectors. The model incorporates time series of climate data (e.g. precipitation, temperature and solar radiation) and physio-geographic information like characteristics of surface water bodies (lakes, reservoirs and wetlands), land cover, soil type, topography and irrigated area. Detailed methodological and model descriptions can be found in Lutter and Giljum (2009) as well as in Flörke et al. (2013) and Alcamo et al. (2003). The model provides data for each water extension. The extensions were then allocated to four EXIOBASE product categories related to livestock production.

Manufacturing industry: Blue water consumption for 53 different sectors

The WaterGAP model was also used for this sector. The model provides data on manufacturing as one single aggregated sector. However, in the previous version of the EXIOBASE the WaterGAP data were provided for seven sub-sectors of manufacturing for the year 2000 . These shares were used to disaggregate the 2007 data on water use and consumption in the manufacturing sector into these seven sub-sectors. In a final step the quantities of water use and consumption were allocated to the 53 different product categories according to shares in total physical output of each sector. The data for physical output were taken from the databases on physical production published by Eurostat and UN Statistics (EUROSTAT 2013; United Nations 2013).

Electricity industry: Blue water consumption are disaggregated into two different types of water cooling systems for seven different types of electricity production 
Data from the WaterGAP model are provided for tower and once-through cooling. For the disaggregation of these two values to the EXIOBASE electricity production product groups, a twostep approach was used. First, the March 2012 version of the World Electric Power Plants database (Platts 2012), was used to estimate how much of the electricity produced in a given country is produced in power plants with tower cooling, once-through cooling, or neither (see Lutter et al. 2013). These shares were used to disaggregate the physical amounts of electricity production per electricity type into tower- and once-through-based electricity production. Next, the overall values of water consumption per cooling system were allocated to the different electricity types via the shares of electricity produced per electricity type and cooling system in overall electricity production in each sector and region.

Domestic use: Blue water consumption

Data were directly adopted from the WaterGAP model. No manipulation steps were needed.

By using water data stemming from hydrological models it is possible to specifically allocate the responsibility for pressures exerted on the environment through water extraction and consumption. Following water accounting concepts, water extraction has to be allocated to the water supply industry which then supplies water to other sectors (e.g. manufacturing). In the input-output logic this supply is accounted for in monetary terms. Consequently, differences in water prices cannot be taken into account due to the assumption of homogenous prices. This inaccuracy is avoided in this paper by allocating water data directly to the sectors using it for production and not the water supplier sector.

\subsection{Spatial disaggregation of agricultural data}

The availability of water resources differs from watershed to watershed, and the European Parliament Water Framework Directive (European Parliament 2000) identified the watershed as the most appropriate level for water management measures. For EXIOBASE 2.2, a matrix was developed that disaggregates the national agricultural water consumption data of the 48 EXIOBASE regions into 10,936 different watersheds around the world (Pfister et al. 2013). This disaggregation was done by splitting the multinational watersheds by country and region borders and aggregating the crop-specific water consumption data from Pfister et al. (2011) to these spatial units. Each sub-watershed was allocated to a country, and for each sector-country combination of EXIOBASE, the share of water consumption taking place in each watershed was calculated based on production volumes and water intensities of the crops summarized in the respective sector. The procedure is analogous to the approach presented in detail by Ewing et al. (2012b) as a "MRIO-Footprint (MRIO-F) model". While their focus is on maintaining the product detail before aggregation into MRIO, our procedure allows us to localize the amount of green and blue water consumed in a country A via import from a specific sector in country B (e.g. blue water consumption of fibre production from country B) with the original distribution of water consumption for this extension across the watersheds of country B. Further details on the disaggregation procedure can be found in the supplementary information. 
Our approach assumes a homogenous delivery of all products within a sector and country to the related production and exporting sectors. In reality the shares of a specific crop being consumed domestically or exported most likely differ between regions and watersheds as well among crops contributing to the same sector in EXIOBASE. The disaggregation matrix is also only provided for agricultural input data, which are the most relevant water consumers on the global level. This limitation is due to the limited availability of spatially-resolved data on water use by industrial activities. In an ideal world, water consumption by power plants, paper industries and other water-intensive activities should be allocated to specific watersheds.

\subsection{Water scarcity analysis}

The spatial disaggregation of water consumption on the watershed level allows us to establish links between water consumption induced by trade and local water scarcity risks. In this paper, we use the blue water scarcity index (BWSI; Hoekstra et al. 2012). Since we could not capture monthly patterns of water consumption in our analysis, we applied the annual indicator that sums the number of months experiencing at least moderate water scarcity during a year. This indicator is accounting for both, duration and severity of water scarcity (0-12 months), which is considered important for assessing social, economic and environmental impacts of water scarcity in watersheds (BWSI; Hoekstra et al. 2012). Multiplying the number of scarce months in each

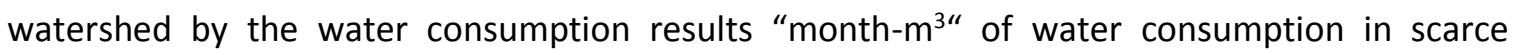
watersheds and serves to identify hotspots of water consumption.

No scarcity assessment is applied for green water consumption (soil moisture reduction), as this indicator reveals trade-offs between land use and water resources rather than absolute water stress. Green water is an ecosystem service of the land occupied and therefore best addressed by land use impact assessment methods (Ridoutt and Pfister 2010), even if it can be depleted over a crop cultivation period.

\section{Results}

In this section, we show the results of the application of EXIOBASE 2.2 for the calculation of water flows embodied in international trade and induced by EU-27 final demand for products. We start with an analysis of the EU's water footprint by country of origin and purpose of water consumption. We then go two steps further, disaggregating to the product group and watershed level. Finally, for the ten watersheds with the largest amounts of water transferred to EU consumption, we analyse the level of prevailing water scarcity as well as the main product water flows from these watersheds into the EU-27. Although the extended EXIOBASE model can produce complete worldwide results, we focus on the global virtual water flows related to the final demand of the EU-27 in this paper.

\subsection{Water consumption by source country and purpose}

When analysing to what extent a country is building its production system and final demand on domestic or foreign resources, W-MRIO can identify the specific country where the water was 
Table 3-1: Quantities of green and blue water consumption embodied in EU-27 final consumption by source country and major water-consuming industrial sector (green water is only consumed in agriculture) in $2007\left(\mathrm{Mm}^{3}\right)$.

\begin{tabular}{|c|c|c|c|c|c|c|}
\hline \multirow{2}{*}{ Source Country } & \multirow{2}{*}{$\begin{array}{c}\text { Green Water } \\
\text { Agriculture }\end{array}$} & \multicolumn{4}{|c|}{ Blue Water } & \multirow{2}{*}{ Total } \\
\hline & & Agriculture & Livestock & Manufacturing & Electricity & \\
\hline Austria & 2,036 & 295 & 39 & 199 & 19 & 2,587 \\
\hline Belgium & 2,171 & 320 & 86 & 751 & 95 & 3,422 \\
\hline Bulgaria & 2,446 & 1,288 & 16 & 90 & 46 & 3,885 \\
\hline Cyprus & 6 & 19 & 3 & 2 & - & 30 \\
\hline Czech Republic & 4,312 & 356 & 34 & 398 & 214 & 5,314 \\
\hline Germany & 22,251 & 3,907 & 321 & 403 & 682 & 27,563 \\
\hline Denmark & 3,546 & 1,394 & 56 & 19 & 7 & 5,022 \\
\hline Estonia & 549 & 8 & 10 & 3 & 10 & 581 \\
\hline Spain & 23,306 & 19,676 & 183 & 73 & 124 & 43,362 \\
\hline Finland & 2,434 & 428 & 24 & 294 & 2 & 3,182 \\
\hline France & 28,447 & 11,057 & 391 & 437 & 810 & 41,143 \\
\hline Greece & 4,855 & 5,986 & 32 & 17 & 52 & 10,943 \\
\hline Hungary & 5,516 & 1,773 & 23 & 68 & 36 & 7,416 \\
\hline Ireland & 809 & 10 & 117 & 59 & 4 & 1,000 \\
\hline Italy & 19,634 & 10,497 & 171 & 1,023 & 114 & 31,440 \\
\hline Lithuania & 1,704 & 26 & 18 & 6 & 14 & 1,769 \\
\hline Luxembourg & 134 & 5 & 1 & 4 & - & 143 \\
\hline Latvia & 975 & 13 & 14 & 35 & - & 1,036 \\
\hline Malta & 207 & 104 & 1 & 0 & - & 312 \\
\hline Netherlands & 1,158 & 536 & 67 & 192 & 49 & 2,002 \\
\hline Poland & 14,817 & 1,167 & 163 & 211 & 199 & 16,557 \\
\hline Portugal & 3,015 & 2,876 & 41 & 47 & 13 & 5,992 \\
\hline Romania & 9,077 & 5,856 & 75 & 101 & 59 & 15,168 \\
\hline Sweden & 2,529 & 837 & 44 & 211 & 13 & 3,635 \\
\hline Slovenia & 450 & 19 & 11 & 1 & 16 & 498 \\
\hline Slovakia & 1,541 & 538 & 15 & 239 & 40 & 2,374 \\
\hline United Kingdom & 9,281 & 1,349 & 280 & 496 & 199 & 11,605 \\
\hline EU-27 & 167,206 & 70,340 & 2,236 & 5,380 & 2,818 & 247,979 \\
\hline USA & 25,659 & 15,391 & 48 & 98 & 116 & 41,312 \\
\hline Japan & 61 & 2 & 0 & 143 & 0 & 208 \\
\hline China & 29,547 & 11,754 & 764 & 3,841 & 448 & 46,355 \\
\hline Canada & 2,886 & 413 & 6 & 38 & 9 & 3,352 \\
\hline South Korea & 151 & 5 & 1 & 70 & 6 & 234 \\
\hline Brazil & 40,610 & 4,439 & 117 & 110 & 4 & 45,280 \\
\hline India & 20,337 & 11,260 & 204 & 547 & 40 & 32,389 \\
\hline Mexico & 639 & 263 & 5 & 21 & 2 & 930 \\
\hline Russia & 4,320 & 1,993 & 55 & 177 & 192 & 6,737 \\
\hline Australia & 692 & 419 & 27 & 3 & 9 & 1,150 \\
\hline Switzerland & 230 & 9 & 6 & 24 & 24 & 293 \\
\hline Turkey & 2,153 & 1,296 & 88 & 259 & 17 & 3,814 \\
\hline Taiwan & 8 & 3 & 1 & 37 & 0 & 49 \\
\hline Norway & 88 & 12 & 5 & 88 & - & 193 \\
\hline Indonesia & 32,993 & 1,962 & 8 & 10 & 4 & 34,978 \\
\hline South Africa & 992 & 355 & 42 & 13 & 28 & 1,429 \\
\hline Rest of Asia \& Pacific & 127,806 & 46,516 & 544 & 1,030 & 100 & 175,995 \\
\hline Rest of America & 68,228 & 13,257 & 278 & 165 & 21 & 81,949 \\
\hline Rest of Europe & 8,066 & 3,292 & 96 & 182 & 137 & 11,773 \\
\hline Rest of Africa & 151,379 & 23,731 & 508 & 824 & 1 & 176,443 \\
\hline Rest of Middle East & 1,513 & 4,033 & 21 & 10 & 37 & 5,614 \\
\hline Total & 685,563 & 210,746 & 5,060 & 13,074 & 4,014 & 918,456 \\
\hline EU domestic share & $24 \%$ & $33 \%$ & $44 \%$ & $41 \%$ & $70 \%$ & $27 \%$ \\
\hline
\end{tabular}


originally consumed for production for export, processing, and final consumption. Table 3-1 illustrates these relationships for the green and blue water consumption induced by the EU-27 final consumption (i.e. the EU-27 water footprint) for the main categories of water consumption - agriculture, livestock, manufacturing and electricity production per region.

The EU-27 countries are considerably dependent on foreign water resources $-76 \%$ of the green water resources have a foreign origin, as do $65 \%$ of the blue water and $73 \%$ of the total consumed water. Within the blue water consumption incorporated in final demand of the EU-27, water consumed for agricultural purposes is clearly dominant. It is also in this category where the share of foreign water resources incorporated in final demand is highest (67\%). This can be explained by environmental conditions, as the climate is favourable for rain-fed agriculture in many European regions compared to countries exporting to the EU-27, which reduces the need for irrigation water. However, also in livestock production and manufacturing the share of foreign water is higher than the domestic resources' share, while it is lower for electricity which is mainly traded within the EU-27 through shared electricity grids.

With regard to almost all source countries the largest share of consumed foreign total (blue and green) water can be attributed to agricultural products (with an average of $90 \%$ in the total), followed by manufactured products $(8 \%)$ and livestock and Electricity ( $1 \%$ each). However, in some cases such as Cyprus or Ireland, the share of water consumption through livestock is above average (with $10 \%$ and $12 \%$ of the total, respectively). A similar situation can be observed for the case of manufactured products where especially Japan and Taiwan are above average with shares of $69 \%$ and $76 \%$ respectively of manufactured products in the total water consumption induced by the EU-27 from these countries.

Even when only considering blue water, in some cases almost $100 \%$ of the blue water consumed by the EU-27 stems from agricultural consumption (e.g. $98 \%$ in the case of Spain). In other cases dominant shares stem from consumption in the manufacturing sector (e.g. $60 \%$ in Belgium or $98 \%$ in Japan) or from livestock breeding (e.g. $61 \%$ in Ireland, mainly through import of fodder).

3.2 Water consumption by product type, source region and source watersheds

In a next step, we further disaggregate the EU-27 water footprints by product type and region of origin. Table 3-2 shows this detailed data, as well as hotspots in the supply chain. 
Table 3-2: Blue water consumption embodied in final consumption of the EU-27 by source region and consumed product group in $2007\left(\mathrm{Mm}^{3}\right)$

\begin{tabular}{|c|c|c|c|c|c|c|c|c|c|c|}
\hline Sector Groups & EU & $\begin{array}{l}\text { Rest of } \\
\text { Europe }\end{array}$ & Africa & Asia & $\begin{array}{l}\text { Latin } \\
\text { America }\end{array}$ & $\begin{array}{l}\text { North } \\
\text { America }\end{array}$ & $\begin{array}{l}\text { Middle } \\
\text { East }\end{array}$ & Australia & World & $\begin{array}{l}\text { Share } \\
\text { in Total }\end{array}$ \\
\hline $\begin{array}{l}\text { Crop products from } \\
\text { agriculture }\end{array}$ & 20,628 & 153 & 4,007 & 7,759 & 4,000 & 2,172 & 620 & 20 & 39,358 & $17 \%$ \\
\hline $\begin{array}{l}\text { Animal products from } \\
\text { agriculture }\end{array}$ & 4,859 & 37 & 297 & 1,642 & 256 & 349 & 22 & 5 & 7,467 & $3 \%$ \\
\hline Products from forestry & 51 & 7 & 212 & 54 & 24 & 11 & 3 & 0 & 363 & $0 \%$ \\
\hline Products from fishing & 31 & 11 & 32 & 36 & 5 & 6 & 2 & 2 & 125 & $0 \%$ \\
\hline $\begin{array}{l}\text { Mining and quarrying } \\
\text { products }\end{array}$ & 8 & -1 & -8 & 61 & 0 & 2 & 2 & 1 & 65 & $0 \%$ \\
\hline $\begin{array}{l}\text { Processed animal } \\
\text { products }\end{array}$ & 9,163 & 314 & 1,998 & 6,031 & 2,192 & 1,783 & 147 & 33 & 21,661 & $9 \%$ \\
\hline Processed crop products & 17,453 & 921 & 5,337 & 13,569 & 5,774 & 5,690 & 675 & 87 & 49,507 & $21 \%$ \\
\hline $\begin{array}{l}\text { Wood, pulp and paper } \\
\text { products }\end{array}$ & 420 & 129 & 139 & 874 & 61 & 61 & 27 & 3 & 1,714 & $1 \%$ \\
\hline Biofuel products & 3 & 0 & 5 & 74 & 106 & 2 & 1 & 0 & 191 & $0 \%$ \\
\hline $\begin{array}{l}\text { Other processed } \\
\text { biomass-based products }\end{array}$ & 1,283 & 521 & 1,942 & 6,580 & 634 & 219 & 118 & 21 & 11,319 & $5 \%$ \\
\hline $\begin{array}{l}\text { Fossil fuel-based } \\
\text { products }\end{array}$ & 900 & 189 & 2,754 & 11,361 & 631 & 589 & 792 & 38 & 17,254 & $7 \%$ \\
\hline $\begin{array}{l}\text { Metal- and mineral- } \\
\text { based products }\end{array}$ & 2,581 & 377 & 1,695 & 10,625 & 678 & 642 & 334 & 51 & 16,982 & $7 \%$ \\
\hline $\begin{array}{l}\text { Electricity, gas and water } \\
\text { supply }\end{array}$ & 1,291 & 108 & 478 & 470 & 70 & 50 & 33 & 4 & 2,503 & $1 \%$ \\
\hline Construction & 2,440 & 160 & 1,055 & 3,226 & 396 & 300 & 172 & 19 & 7,768 & $3 \%$ \\
\hline $\begin{array}{l}\text { Sales and retail services } \\
\text { (incl. hotels/restaurants) }\end{array}$ & 12,432 & 484 & 2,702 & 8,710 & 2,224 & 2,339 & 511 & 104 & 29,506 & $13 \%$ \\
\hline $\begin{array}{l}\text { Transport, storage and } \\
\text { communication services }\end{array}$ & 620 & 61 & 355 & 1,260 & 143 & 152 & 71 & 10 & 2,673 & $1 \%$ \\
\hline $\begin{array}{l}\text { Financial and business } \\
\text { services }\end{array}$ & 1,377 & 99 & 498 & 2,049 & 274 & 307 & 104 & 13 & 4,721 & $2 \%$ \\
\hline Other services & 5,233 & 304 & 2,005 & 8,999 & 1,214 & 1,446 & 468 & 46 & 19,716 & $8 \%$ \\
\hline Total & 80,774 & 3,875 & 25,502 & 83,382 & 18,682 & 16,119 & 4,101 & 458 & 232,894 & $100 \%$ \\
\hline Share in Total & $35 \%$ & $2 \%$ & $11 \%$ & $36 \%$ & $8 \%$ & $7 \%$ & $2 \%$ & $0.2 \%$ & $100 \%$ & \\
\hline
\end{tabular}

Note: Negative values in "Mining and quarrying products" are the result of negative stock changes, meaning that products with embodied water were purchased in the previous year but consumed in the year of observation.

This analysis provides a comprehensive and detailed overview of the international hydrologicaleconomic structure of water flows. The largest amount of blue water is consumed through the 
consumption of processed crop products, which holds a share of $21 \%$ in total blue water consumption. This product group is followed by crop products stemming directly from the agricultural sector (17\%) and sales and retail services, which include consumption of hotels and restaurants (13\%). Asia plays a crucial role in providing the EU-27 with water embodied in imported products. Thereby, larger quantities of water flow from Asia to the EU-27 embodied in processed food products than in raw agricultural products, while within the EU the water impact of raw and processed agricultural products is quite similar. Other important providers of blue water via processed biomass-based products are Africa, Latin America and North America.

\subsection{Linking 'virtual' water flows at the watershed level to water scarcity assessments}

One of the most innovative aspects of the EXIOBASE 2.2 as a comprehensive tool to perform WMRIO-type assessments is its ability to disaggregate the origin of agricultural water consumption to individual watersheds. This means that for every region in EXIOBASE 2.2, water consumed through agricultural extensions can be traced back to the location of the source agricultural products such as rice or wheat. Figure 3-1 illustrates the blue water consumption induced by European final consumption per sub-watershed in the year 2007. 
(a)

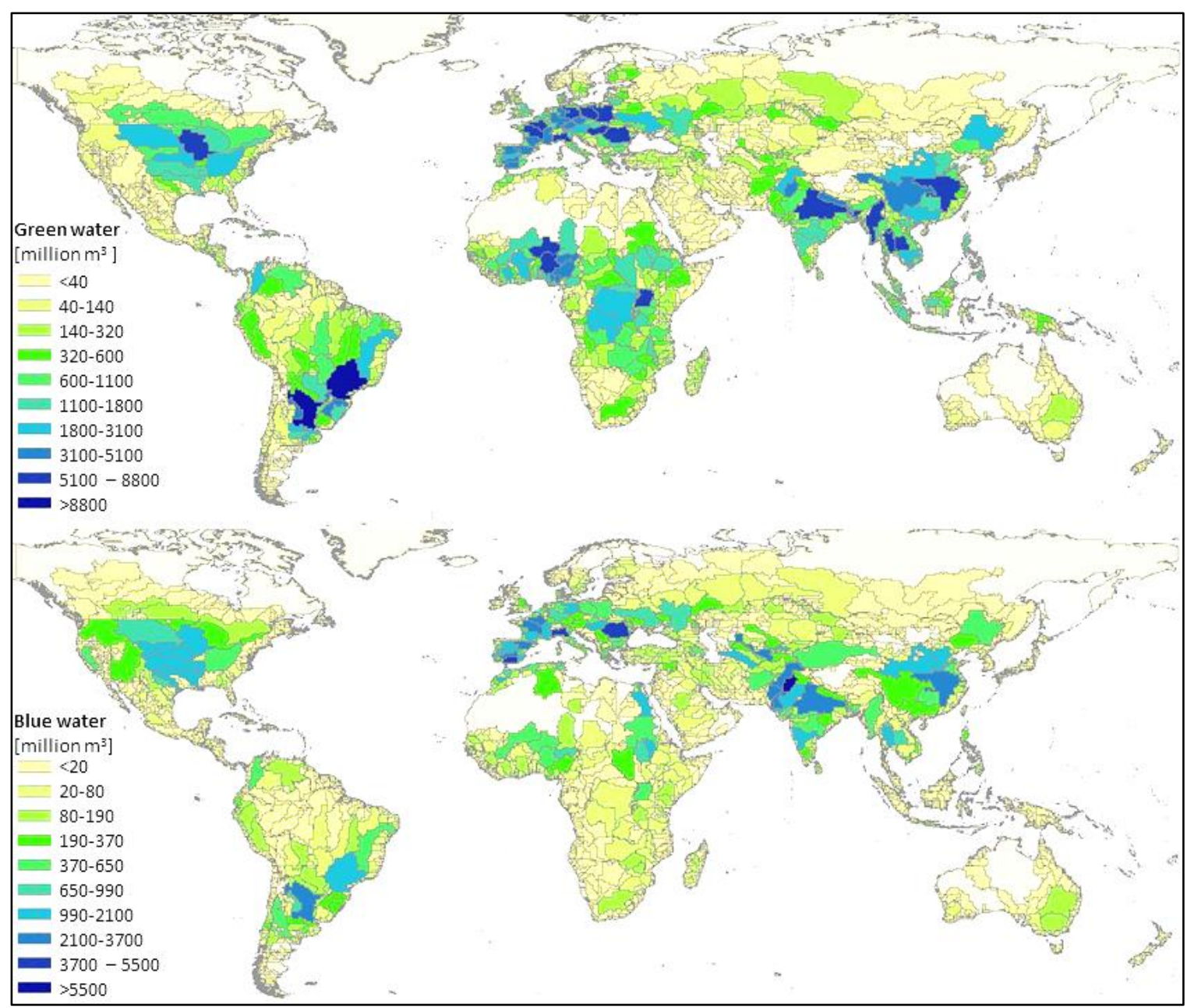

Figure 3-1: Green (a) and blue (b) water consumption induced by EU27 final consumption in the year 2007. White areas indicate watersheds with no contribution to EU27 consumption.

The lower part of Figure 3-1 shows that large quantities of blue irrigation water consumed comes from watersheds that focus on large-scale irrigated agriculture in watersheds outside Europe, such as the Indus (Pakistan and India; 20 billion $\mathrm{m}^{3}$ ), the Mississippi (mainly Mid-West US; 9 billion $\mathrm{m}^{3}$ ), the Nile (mainly Egypt and Sudan; $\sim 5$ billion $\mathrm{m}^{3}$ ), the Parana (mainly Argentina and Southern Brazil; $\sim 4$ billion $\mathrm{m}^{3}$ ), the Amu Darya (central Asia; 4 billion $\mathrm{m}^{3}$ ), the Syr Darya (central Asia; 2 billion $\mathrm{m}^{3}$ ), the Ganges (northern India and Bangladesh; $\sim 4$ billion $\mathrm{m}^{3}$ ), and the Yangtse and Hei River in China ( $\sim 2$ billion $\mathrm{m}^{3}$ each). Within Europe, the Danube River (mainly Hungary and Romania), the Guadalquivir (Southern Spain) and the Po (Northern Italy) contribute the largest irrigation water quantities for European final consumption, with $\sim 9$ billion $\mathrm{m}^{3}, \sim 5$ billion $\mathrm{m}^{3}$ and $\sim 5$ billion $\mathrm{m}^{3}$, respectively.

In Table 3-3 we show more detailed results for the largest foreign water flow identified in Chapter 3.2: water consumption via processed crop products with a source watershed in Asia. Data are shown disaggregated into the top-15 source watersheds, which together make up for around $60 \%$ of this flow. 
Table 3-3: Blue water consumption embodied in final consumption of the EU-27 of processed crop products with source watershed in Asia; top-15 source watersheds and originally produced product in $2007\left(\mathrm{Mm}^{3}\right)$

\begin{tabular}{|c|c|c|c|c|c|c|c|c|c|c|}
\hline Rivershed & Region & $\begin{array}{l}\text { Paddy } \\
\text { rice }\end{array}$ & Wheat & $\begin{array}{l}\text { Other } \\
\text { cereal } \\
\text { grains }\end{array}$ & $\begin{array}{c}\text { Vege- } \\
\text { tables, } \\
\text { fruit, } \\
\text { nuts }\end{array}$ & Oil seeds & $\begin{array}{c}\text { Sugar } \\
\text { cane, } \\
\text { sugar } \\
\text { beet }\end{array}$ & $\begin{array}{l}\text { Other } \\
\text { crops }\end{array}$ & Total & $\begin{array}{c}\text { Share in } \\
\text { Total }\end{array}$ \\
\hline Yangtze & China & 116.29 & 74.79 & 26.02 & 11.32 & 49.29 & 1.11 & 5.09 & 283.91 & $4 \%$ \\
\hline Hai River & China & 2.04 & 94.79 & 68.00 & 17.21 & 26.90 & 0.05 & 3.41 & 212.41 & $3 \%$ \\
\hline Yellow River & China & 3.60 & 82.54 & 47.90 & 9.84 & 21.96 & 0.50 & 3.78 & 170.12 & $2 \%$ \\
\hline Indus & $\begin{array}{l}\text { China, India, RoW } \\
\text { Asia \& Pacific }\end{array}$ & 469.13 & 2017.95 & 348.14 & 161.19 & 1165.64 & 210.55 & 176.36 & 4548.94 & $57 \%$ \\
\hline Ganges & $\begin{array}{l}\text { China, India, RoW } \\
\text { Asia \& Pacific }\end{array}$ & 75.67 & 88.30 & 6.15 & 55.64 & 241.33 & 50.12 & 39.45 & 556.67 & $7 \%$ \\
\hline Krishna & India & 19.54 & 1.32 & 6.42 & 19.16 & 163.40 & 7.05 & 5.97 & 222.86 & $3 \%$ \\
\hline Godavary & India & 20.68 & 0.93 & 1.31 & 13.06 & 59.06 & 4.26 & 4.36 & 103.67 & $1 \%$ \\
\hline Irrawaddy & $\begin{array}{l}\text { India, RoW Asia \& } \\
\text { Pacific }\end{array}$ & 8.06 & 0.33 & 0.78 & 22.79 & 68.40 & 3.16 & 8.36 & 111.89 & $1 \%$ \\
\hline Don & Russia & 0.37 & 43.69 & 16.07 & 0.11 & 242.85 & 16.05 & 0.31 & 319.46 & $4 \%$ \\
\hline Aral Drainage & RoW Asia \& Pacific & 27.03 & 142.43 & 34.25 & 56.84 & 495.91 & 0.97 & 94.45 & 851.89 & $11 \%$ \\
\hline Amu Darya & RoW Asia \& Pacific & 16.67 & 137.08 & 22.58 & 39.45 & 336.76 & 0.51 & 74.73 & 627.78 & $8 \%$ \\
\hline Syr Darya & RoW Asia \& Pacific & 8.94 & 69.60 & 12.27 & 20.89 & 190.20 & 0.28 & 31.49 & 333.67 & $4 \%$ \\
\hline Chao Phraya & RoW Asia \& Pacific & 100.85 & & 4.47 & 33.75 & 75.01 & 18.55 & 7.41 & 240.04 & $3 \%$ \\
\hline Mekong & RoW Asia \& Pacific & 55.95 & & 2.52 & 59.43 & 71.07 & 15.89 & 17.15 & 222.02 & $3 \%$ \\
\hline Brahmaputra & RoW Asia \& Pacific & 12.75 & 0.00 & 0.00 & 29.36 & 34.53 & 4.83 & 24.20 & 105.67 & $1 \%$ \\
\hline Total & & 937.56 & 2753.75 & 596.89 & 550.05 & 3242.31 & 333.90 & 496.53 & 8009.59 & $100 \%$ \\
\hline Share in Total & & $12 \%$ & $34 \%$ & $7 \%$ & $7 \%$ & $40 \%$ & $4 \%$ & $6 \%$ & $100 \%$ & \\
\hline
\end{tabular}

By far the largest water flows from Asian watersheds with considerable water scarcity levels into European consumption of processed crop products comes from the Indus watershed. $57 \%$ of the total water flowing via processed crop products into EU-27. The Aral Drainage (11\%), the Amu Darya (8\%) and the Ganges (7\%) together make up for another quarter. In general, oil crops play an important role in this product category with a total share of $40 \%$, followed by wheat $(34 \%)-$ both produced extensively in the Indus watershed - and paddy rice (12\%; mainly in the Indus, Yangtze and the Chao Phraya watershed in Thailand). 
However, the absolute quantities themselves are not the best proxy for the impact caused by the water appropriation (Ridoutt and Pfister 2010). It is important to link these quantities to data on water scarcity (compare Chapter 2.3). Table 3-4 shows that some of the watersheds contributing most to the blue water consumption are at low water scarcity risk (i.e. a respective low number of months with water scarcity; column 3), such as the Danube or Parana rivers. On the other hand, rivers with lower water consumption become more relevant, such as the Amu Darya, Ganges, Hai or Chao Phraya rivers in Asia or the Guadiana, Douro and Tagus on the Iberian Peninsula, as by means of the low consumption levels the pressure on water scarce areas is less accentuated. It is troubling that three of the top four watersheds regarding blue water consumption also rank highest concerning water scarcity (Indus, Guadalquivir and Mississippi), which indicates that many regions exporting irrigated crops face water scarcity. Water scarcity in the Indus watershed are related to both Pakistani and Indian production, mainly of wheat and oil seeds. What is an additional concern is that almost $80 \%$ of water scarcity weighted water consumption occurs outside Europe, while only $2 / 3$ of water consumption occurs outside. The water scarcity impact from the production in the Indus basin for EU consumption is worse than the water scarcity impact from total internal EU water consumption.

Table 3-4: Source watersheds for final consumption of the EU-27 $\left(\mathrm{Mm}^{3}\right)$, comparing highest blue water consumption (BW) and highest waters scarcity rates in 2007 , sorted by water scarcity

\begin{tabular}{|l|c|c|c|c|}
\hline Watershed & $\begin{array}{c}\text { EU-27 BW } \\
{\left[\mathbf{M m}^{3}\right]}\end{array}$ & $\begin{array}{c}\text { Blue water scarcity } \\
\text { [no. of months] }\end{array}$ & $\begin{array}{c}\text { EU-27 induced water scarcity } \\
{\left[\mathbf{M m}^{3} \text { month] }\right.}\end{array}$ & Rank BW \\
\hline Indus & $25^{\prime} 107$ & 12 & $297^{\prime} 556$ & 1 \\
\hline Guadalquivir & $5^{\prime} 459$ & 7 & $38^{\prime} 216$ & 4 \\
\hline Mississippi & $8^{\prime} 895$ & 4 & $25^{\prime} 610$ & 9 \\
\hline Ganges & $3^{\prime} 658$ & 7 & $22^{\prime} 818$ & 11 \\
\hline Guadiana & $3^{\prime} 259$ & 7 & $22^{\prime} 239$ & 19 \\
\hline Hai river & $1^{\prime} 853$ & 12 & $20^{\prime} 202$ & 8 \\
\hline Amu Darya & $4^{\prime} 040$ & 5 & $13^{\prime} 662$ & 13 \\
\hline Douro & $2^{\prime} 732$ & 5 & $12^{\prime} 924$ & 14 \\
\hline Tagus & $2^{\prime} 584$ & 5 & $10^{\prime} 587$ & 22 \\
\hline Chao Phraya & $1^{\prime} 512$ & 7 & $10^{\prime} 434$ & 10 \\
\hline Ebro & $3^{\prime} 478$ & 3 & $9^{\prime} 701$ & 5 \\
\hline Nile & $4^{\prime} 850$ & 2 & $8^{\prime} 552$ & 7 \\
\hline Po & $4^{\prime} 276$ & 2 & 0 & 2 \\
\hline Danube & $9^{\prime} 485$ & 0 & 0 & 6 \\
\hline Parana & $4^{\prime} 472$ & 0 & & \\
\hline
\end{tabular}

The following Table 3-5 illustrates EU-27 blue and green water consumption induced in watersheds with high scarcity levels by type of final product and watershed. We show here both, blue and green water, as in scarcity situations also green water consumption increases the pressure on the environment. In the majority, three main types of products show high values of 
water consumption - processed crop products, crop products from agriculture, and sales and retail services. This is similar to the analyses carried out for the largest water flow into EU-27 consumption (for processed crop products from Asia) but it holds also true for European watersheds such as the Guadalquivir or the Po river. Processed animal products also show considerably high levels of water consumption. The large values for fossil fuel-based products in some watersheds are the result of the upstream trade relationships of products like petrochemicals. 
Table 3-5: EU-27 blue and green water consumption $\left(\mathrm{Mm}^{3}\right)$ induced in watersheds with high scarcity levels by type of final product and watershed, 2007; colouring indicates largest flows within watershed

\begin{tabular}{|c|c|c|c|c|c|c|c|c|c|c|c|c|c|}
\hline Final product / Watershed & Indus & $\begin{array}{l}\text { Quadal- } \\
\text { quivir }\end{array}$ & $\begin{array}{l}\text { Missis- } \\
\text { sippi }\end{array}$ & Ganges & Guadiana & Hai River & $\begin{array}{l}\text { Amu } \\
\text { Darya }\end{array}$ & Douro & Tagus & $\begin{array}{l}\text { Chao } \\
\text { Phraya }\end{array}$ & Ebro & Nile & Po \\
\hline $\begin{array}{l}\text { Crop products from } \\
\text { agriculture }\end{array}$ & 191.7 & 178.8 & 1771.5 & 52.1 & 132.2 & 251.6 & 35.4 & 217.8 & 88.0 & 62.6 & 231.5 & 3162.9 & 198.3 \\
\hline $\begin{array}{l}\text { Animal products from } \\
\text { agriculture }\end{array}$ & 1837.9 & 1565.2 & 299.9 & 1815.4 & 1725.9 & 14.7 & 380.0 & 1274.2 & 1015.9 & 602.0 & 1817.0 & 207.9 & 2870.6 \\
\hline Products from forestry & 16.7 & 1.2 & 7.7 & 2.7 & 0.8 & 0.5 & 3.4 & 0.9 & 0.5 & 7.6 & 1.0 & 166.8 & 0.5 \\
\hline Products from fishing & 9.6 & 6.8 & 5.2 & 6.8 & 3.8 & 1.4 & 1.2 & 4.0 & 2.2 & 3.2 & 4.7 & 31.4 & 3.0 \\
\hline $\begin{array}{l}\text { Mining and quarrying } \\
\text { products }\end{array}$ & 25.0 & 0.3 & 1.6 & 2.7 & 0.2 & 1.8 & 2.7 & 0.2 & 0.1 & 8.0 & 0.2 & 0.5 & 0.2 \\
\hline Processed animal products & 1928.6 & 947.8 & 1646.3 & 453.9 & 475.6 & 259.7 & 285.7 & 477.2 & 277.1 & 543.0 & 582.1 & 1681.9 & 1264.2 \\
\hline Processed crop products & 4878.6 & 3570.9 & 5333.5 & 1263.0 & 1565.0 & 398.2 & 627.8 & 1316.3 & 871.1 & 1258.8 & 1688.6 & 5276.4 & 2452.8 \\
\hline $\begin{array}{l}\text { Wood, pulp and paper } \\
\text { products }\end{array}$ & 188.9 & 18.3 & 45.7 & 35.9 & 9.0 & 54.2 & 22.4 & 9.7 & 5.3 & 61.0 & 11.4 & 120.0 & 26.5 \\
\hline Biofuel products & 43.9 & 0.2 & 1.5 & 1.5 & 0.1 & 0.4 & 4.5 & 0.1 & 0.1 & 13.7 & 0.1 & 4.4 & 0.1 \\
\hline $\begin{array}{l}\text { Other processed biomass- } \\
\text { based products }\end{array}$ & 1493.5 & 106.3 & 180.8 & 667.1 & 59.2 & 450.1 & 206.5 & 62.3 & 34.3 & 554.3 & 72.9 & 1450.2 & 147.2 \\
\hline Fossil fuel-based products & 5342.4 & 52.4 & 503.3 & 614.7 & 25.1 & 197.3 & 610.2 & 26.8 & 14.7 & 1699.2 & 30.8 & 2557.5 & 62.0 \\
\hline $\begin{array}{l}\text { Metal- and mineral-based } \\
\text { products }\end{array}$ & 2454.8 & 163.2 & 503.9 & 519.9 & 81.8 & 893.2 & 292.2 & 88.8 & 48.4 & 789.0 & 103.9 & 1442.7 & 322.8 \\
\hline $\begin{array}{l}\text { Electricity, gas and water } \\
\text { supply }\end{array}$ & 150.0 & 16.7 & 34.7 & 32.9 & 8.7 & 17.3 & 20.2 & 9.5 & 5.1 & 49.9 & 11.1 & 408.6 & 19.1 \\
\hline Construction & 968.6 & 247.0 & 253.7 & 232.3 & 128.2 & 157.6 & 125.1 & 149.3 & 77.1 & 315.6 & 170.6 & 877.9 & 187.4 \\
\hline $\begin{array}{l}\text { Sales and retail services } \\
\text { (incl. hotels/restaurants) }\end{array}$ & 2429.9 & 2675.0 & 2149.2 & 1874.3 & 1468.0 & 374.1 & 315.5 & 1820.2 & 900.3 & 675.9 & 2048.1 & 2437.3 & 2129.7 \\
\hline $\begin{array}{l}\text { Transport, storage and } \\
\text { communication services }\end{array}$ & 310.7 & 64.8 & 129.0 & 226.7 & 34.0 & 80.7 & 38.4 & 39.4 & 20.5 & 95.3 & 45.4 & 314.1 & 133.9 \\
\hline $\begin{array}{l}\text { Financial and business } \\
\text { services }\end{array}$ & 590.0 & 148.3 & 268.2 & 261.0 & 80.2 & 114.3 & 73.1 & 95.8 & 48.6 & 179.9 & 109.3 & 436.8 & 178.5 \\
\hline Other services & 3545.3 & 715.5 & 1296.2 & 638.0 & 384.9 & 320.4 & 427.1 & 454.7 & 232.4 & 1088.3 & 524.9 & 1806.6 & 489.6 \\
\hline Total & 26405.9 & 10478.7 & 14431.8 & 8700.8 & 6182.6 & 3587.5 & 3471.4 & 6047.2 & 3641.4 & 8007.5 & 7453.5 & 22383.7 & 10486.3 \\
\hline
\end{tabular}




\section{Discussion}

\subsection{Water - a resource with international supply flows}

The W-MRIO analyses presented in this paper quantify overall, blue and green water consumption in the whole supply chain of products consumed in each country. We showed that, as with regard to other resource categories, such as raw materials, carbon or land (see Tukker et al. 2014), Europe is a major net-importer of water embodied in internationally traded products. This statement holds true for both types of water flows - blue and green water - and for all fields of water appropriation included in this analysis (agriculture, electricity, etc.). The main product group causing water consumption for final imports into the EU-27 are (processed) biomass-based products, with Asia and Latin America playing a major role as water suppliers. We further illustrated that the major share of water is abstracted in only a few watersheds, including in the north of India (Indus and Ganges rivers) and the east of China (lower Yangtze and Yellow rivers) and to a lesser extent in the Rio Paraná watershed in South America and a number of watersheds in North America and the Nile. Furthermore, many of these watersheds are already highly water scarce and therefore the share of water scarcity impacts occurring outside the EU-27 is even higher. Such information sheds light on the EU's responsibility for water stress in foreign watersheds. The highly disaggregated data stemming from our assessments allow us to pinpoint supply chains serving final demand of the EU-27 which require specific political attention, as they increase the pressure on scarce water resources outside the EU-27 boarders. These are for instance processed crop products, such as cotton, stemming from the Indus or Ganges river, sales and retail services from Ganges, or animal products from the Indus or Ganges river. In the following section we show policy areas and strategies that can be informed by the type of analysis presented in this paper.

\subsection{Informing policy making}

The setup of the EXIOBASE 2.2 as state-of-the-art W-MRIO was triggered by ongoing policy debates and demand for robust science-based answers to policy questions in the context of achieving more sustainable patterns of natural resource use in Europe (for instance, European Commission 2011b). Carrying out analyses on global water flows induced by European final demand and addressing the responsibility for water stress impacts caused in other regions is in line with European policies such as the "Blueprint to Safeguard Europe's Water Resources" (European Commission 2012), the Water Framework Directive (European Parliament and Council 2000), and the "Roadmap to a resource-efficient Europe" (European Commission 2011a).

In the Blueprint the Commission focuses on better implementing current water legislation, integrating water policy objectives into other policies, and filling the water quantity and efficiency gaps. This strategy describes required action with regard to the management of European waters, as well as the need to consider the global aspects of water use and water management related to European production and consumption patterns. Our results support policy making in this regards by identifying world-wide hotspots of water consumption related to final demand for products 
and services in the EU-27. Inducing increased water stress abroad through European consumption would neither be in line with the Blueprint's objectives, nor with the official European development policy agenda (for instance, European Commission 2011d). Hence, based on the results of this study, European trade strategies - such as the Economic Partnership Agreements (EPAs) negotiated between the EU and African, Caribbean and Pacific (ACP) partners - can be aligned with development strategies such as the Agenda for Change (European Commission 2011c) or the European approach towards pursuing the Sustainable Development Goals (SDG) (European Commission 2015).

This study is also the response to the demand that effective water management strategies cannot be implemented only at national levels, but have to be designed for the watershed level, as was emphasized in the Water Framework Directive (European Parliament and Council 2000). By linking our results with water scarcity assessments we can identify pressures exerted on water resources world-wide, which can in subsequent work be analysed in higher detail with approaches taking into account local hydrological, environmental and social circumstances of the respective watersheds. Only with such detailed analysis the specific impacts of water withdrawal in waterrich or dry watersheds can be quantified.

Another example of assuming consumers' responsibility based on the quantitative assessments made in this paper is the area of different diets prevailing in the EU-27 and the implications of possible changes on water consumptions abroad. Water intensive diets, such as those with a high share in meat and other animal products or with supply starting in watersheds with high levels of irrigation, could be addressed actively in the design and implementation of policy measures such as the Strategy for Europe on Nutrition, Overweight and Obesity related health issues (European Commission 2007). Here, the focus on a more healthy diet would result in multiple positive effects, one of them being a reduced EU-27 global water footprint which is largely outsourced.

In addition to the consumer's perspective and responsibility, the producer's perspective is also of key importance. In cases where a country uses high amounts of water for producing a specific export good, a disregard of water stress caused by this export-driven production would, in the medium to long run, result in an irreversible damage to the water system with severe consequences for continued export-oriented production. To avoid such impacts, a consequent management approach would be to analyse (1) whether the same product could be produced with higher water efficiency, (2) whether the same product could be produced in a different watershed within the respective country, (3) the local circumstances and management options to better distribute water resources among different users, and (4) whether the production could be replaced by the production of a different, less water-intensive product. Our analysis can help comparing different production systems globally and thereby help assessing the relative performance of different production options on the global market.

In the end, the producing country and the country finally consuming the exported products both share the responsibility for the impacts caused by production in water scarce areas. Hence, one way of assuming responsibility at the consumer's side would be to actively collaborate with the trade partners to carry out the analyses identified above and to collectively design management 
measures. For the case of the Indus, this could be done, for instance, in the context of the negotiations of the free trade agreement (FTA) between the EU and India. The illustration of the currently occurring external costs form water embodied in final consumption provides at least a basis to include these environmental aspects in the FTA. For instance, trade agreements could foresee compensation payments for external costs occurring in exporter countries based on principles of shared responsibility. Thereby they could pave the way for establishing consumer payment schemes covering external costs in traded products which are invested in producer regions for mitigating water related problems. Additionally integration of these external costs would regulate demand through increased prices of final products and potentially contribute to reducing over-consumption of food.

In general, the Water Framework Directive is an appropriate management tool that can be implemented in other geographical regions. Its harmonised system to assess and evaluate the status quo of available water resources as well as the management approach by means of river basin management plans are globally applicable, and the EU could assist in its adaptation and implementation, as is already done in the Mediterranean region (for instance, Choukr-Allah et al. 2012).

\subsection{Improving data and methodology}

For this paper, data on water consumption on a very high level of detail was used for agricultural production, and for the first time agricultural water consumption data embodied in international trade as calculated through W-MRIO were disaggregated to the watershed level, with a consequent scarcity assessment. However, caution is needed when interpreting the results, and special attention should be given with regard to the following issues:

Data coverage of water withdrawal and consumption on a high level of sectoral disaggregation is limited to the agricultural sector. Efforts should therefore be put into the collection or estimation of water consumption in industrial processes, in order to improve coverage and meaningfulness of the model results. Hydropower production has an especially large contribution (Mekonnen and Hoekstra 2011b; Pfister et al. 2011a), and more research is needed to properly quantify water use related to this sector.

So far, mainly modelled data are available in a level of detail appropriate for W-MRIO application. The aim should be to compile a comprehensive dataset on water withdrawal and consumption on a detailed sector level, at least for Europe. The foundations for this data compilation effort have been laid e.g. by the SEEA Water (United Nations 2012) or the efforts of Eurostat to set up a system of water accounts (EUROSTAT 2014). However, the accounting frameworks still lack the data to populate them and all measured data refers to withdrawal, while the main interest from a hydrological system's point of view is on water consumption, which cannot be measured directly.

The disaggregation matrix is provided only for the agricultural input data. This is due to the limited data availability regarding spatial distribution of water requirements per industrial activity. In an ideal world, water use and consumption by power plants, paper industries and other activities 
should be allocated spatially explicit to specific watersheds. However, for this paper we had to limit the analysis to the agricultural sectors, which are the most relevant water consumers on the global level.

With regard to spatial disaggregation, the aim in this study was to introduce a high level of detail through disaggregating the extensions of water appropriation to the watershed level. However, while the EXIOBASE 2.2 has a large number of 48 countries and regions, the spatial resolution of the MRIO outside Europe is still an area with potential for improvement, as it induces high uncertainties of potential origins, especially since the five "rest of the world" regions in reality consist of a large number of countries and watersheds, which will not equally contribute to the exports of different regions. Also, while the regional country groups account for only about $5 \%$ of global GDP in 2007 (Wood et al. 2015), almost 40\% of the global territorial water consumption takes place there. Additionally, the assumption of equal shares for export and domestic use of every production model cell becomes more problematic in larger regions, where export production might concentrate in specific sub-regions.

A significant shortcoming of $I O$ analysis is the fact that most MRIO models work on the level of aggregated economic sectors and product groups. This fact implies that each sector produces a homogenous product output. As a consequence, in one sector, a number of different products with potentially very different water intensities are mixed together and averaged. This homogeneity assumption leads to distortions of results, for example, when very different products are aggregated into one sector (for instance, for the case of materials, Schoer et al. 2012). For instance, the EXIOBASE discerns eight different sectors of crop production, which is a good start but still reduces the level of detail from 160 crops to eight sectors. It thereby assumes a homogenous delivery of all products within a sector and country to the related production and exporting sectors. In reality the shares of a specific crop being consumed domestically or exported most likely differ between regions and watersheds, as well among crops contributing to the same sector. To improve this aspect in future, our analysis might be combined with other approaches aiming at calculating footprint-type indicators with higher crop detail, such as Ewing et al. (2012b).

Temporal disaggregation into monthly water consumption would improve the quality of blue water scarcity assessment. However, by assuming the number of months experiencing at least moderate scarcity in each year, the criticality dimension was included (Hoekstra et al. 2012) and helped to identify hotspots by combining blue water scarcity and consumption in a single number for each watershed.

Finally, for this paper calculations were carried out only for the year 2007. EXIOBASE time series data covering the period of 1995-2011 - with now-casts up to 2016 - are currently being built in another European research project (DESIRE; see www.fp7desire.eu). This expanded database will provide a comprehensive basis for analyses of historical trends as well as estimation of future developments and scenario modelling, and thus help understanding the structural and efficiency changes of different regions and sectors. 
Further discussions on advantages and improvement potentials of top-down approaches are found in the SI.

\section{Conclusions}

Responsible resource management takes into account not only the territorial or regional situation but also the international dimension. Today, a large share of the goods and services consumed in the EU-27 are imported from elsewhere bringing along large quantities of incorporated water. Knowing also about the environmental impacts in terms of increased water scarcity induced by the consumption of specific products allows to develop policy measures which decrease the pressure put on the environment not only within the EU but also elsewhere.

Multi-regional input-output analysis extended by data on water appropriation is a comprehensive approach which allows calculating water footprints for all products or industries, even with very complex global supply chains. MRIO also enables the identification of the geographical origin of these virtual water flows. Ideally bottom-up and top-down approaches should come up with the same amounts of overall water appropriation. However, given the current data and methodological limitations, a top-down approach such as W-MRIO will remain the most comprehensive approach to allocate comprehensively water appropriation to final consumption, while bottom-up approaches have their specific strengths in the analysis of individual products.

With our research we realised an important step towards informing more responsible water policy making, as the water footprints of total final demand in the EU-27 at a very detailed level of product and geographical detail has been quantified for the first time. We disaggregated the virtual water flows to the watershed level, and compared this information with data on water scarcity levels to identify those watersheds where European consumption is causing severe impacts.

Expanding such analyses in the future, especially by calculating time series and including monthly water consumption, will allow better understanding of current trends in direct and indirect water consumption and scarcity impacts, and better evaluation of targeted policy measures. 


\section{References}

Alcamo, J., P. Döll, T. Henrichs, F. Kaspar, B. Lehner, T. Rosch, and S. Siebert. 2003. Development and testing of the WaterGAP 2 global model of water use and availability. Hydrological Sciences J 48(3): 317-337.

Allan, J. A. 1994. Overall perspectives on countries and regions. In Water in the Arab World: perspectives and prognoses., edited by P. Rogers, Lydon, P. Cambridge: Harvard University Press.

Bruckner, M., S. Giljum, C. Lutz, and K. Wiebe. 2012. Materials embodied in international trade Global material extraction and consumption between 1995 and 2005. Global Environmental Change 22: 568-576.

Cazcarro, I., R. Duarte, and J. Sánchez-Chóliz. 2012. Water flows in the Spanish economy: agrifood sectors, trade and households diets in an input-output framework. Environmental Science \& Technology 46(12): 6530-6538.

Cazcarro, I., R. Duarte, and J. Sánchez Chóliz. 2013. Multiregional Input-Output Model for the Evaluation of Spanish Water Flows. Environmental Science \& Technology 47(21): 1227512283.

Choukr-Allah, R., R. Ragab, and R. Rodriguez-Clemente. 2012. Integrated Water Resources Management in the Mediterranean Region. Dialogue Towards New Strategy. Dordrecht, Heidelberg, New York, London: Springer.

Cranston, G. R. and G. P. Hammond. 2012. Carbon footprints in a bipolar, climate-constrained world. Ecological Indicators 16: 91-99.

Dietzenbacher, E. and E. Velázquez. 2007. Analysing Andalusian Virtual Water Trade in an InputOutput Framework. Reagional Studies 41(2): 185-196.

Dietzenbacher, E., B. Los, R. Stehrer, M. Timmer, and G. de Vries. 2013. The Construction of World Input-Output Tables in the WIOD Project. Economic Systems Research 25(1): 71-98.

EEA. 2014. Environmental Terminology and Discovery Service (ETDS). Consumptive use (of water). http://glossary.eea.europa.eu/terminology/concept html?term=consumptive\%20use\% 20\%28of\%20water\%29. Accessed 2014 09.10.

European Commission. 2007. A Strategy for Europe on Nutrition, Overweight and Obesity related health issues $\operatorname{COM(2007)~279.~Brussels:~}$

European Commission. 2011a. Roadmap to a Resource Efficient Europe. COM(2011) 571 final. Brussels: European Commission.

European Commission. 2011b. Roadmap to a resource efficient Europe. In COMMUNICATION FROM THE COMMISSION TO THE EUROPEAN PARLIAMENT, THE COUNCIL, THE EUROPEAN ECONOMIC AND SOCIAL COMMITTEE AND THE COMMITTEE OF THE REGIONS Brussels: EC.

European Commission. 2011c. Increasing the impact of EU Development Policy: an Agenda for Change $\operatorname{COM(2011)637.~Brussels:~}$

European Commission. 2011d. Increasing the impact of EU Development Policy: an Agenda for Change. $\operatorname{COM(2011)~} 571$ final. Brussels: European Commission.

European Commission. 2012. A Blueprint to Safeguard Europe's Water Resources. Brussels: European Commission.

European Commission. 2015. A Global Partnership for Poverty Eradication and Sustainable Development after 2015. COM(2015) 44 final. Brussels: 
European Parliament and Council. 2000. Directive 2000/60/EC of the European Parliament and of the Council of 23 October 2000 establishing a framework for Community action in the field of water policy.

European Parliament, C. 2000. Directive 2000/60/EC of the European Parliament and of the Council of 23 October 2000 establishing a framework for Community action in the field of water policy.

EUROSTAT. 2013. PRODCOM Database. Luxembourg: Statistical Office of the European Communities.

EUROSTAT. 2014. Personal Communication with EUROSTAT, Draft manual for physical water flow accounts (PWFA). Luxembourg 2014.

Ewing, B. R., T. R. Hawkins, T. O. Wiedmann, A. Galli, A. Ertug Ercin, J. Weinzettel, and K. SteenOlsen. 2012a. Integrating ecological and water footprint accounting in a multi-regional input-output framework. Ecological Indicators 23: 1-8.

Ewing, B. R., T. R. Hawkins, T. O. Wiedmann, A. Galli, A. E. Ercin, J. Weinzettel, and K. Steen-Olsen. 2012b. Integrating ecological and water footprint accounting in a multi-regional inputoutput framework. Ecological Indicators 23: 1-8.

Feng, K., A. Chapagain, S. Suh, S. Pfister, and K. Hubacek. 2011. Comparison of bottom-up and topdown approaches to calculating the water footprints of nations. Economic Systems Research 23(4): 371-385.

Flörke, M., E. Kynast, I. Bärlund, S. Eisner, F. Wimmera, and J. Alcamo. 2013. Domestic and industrial water uses of the past 60 years as a mirror of socio-economic development: $A$ global simulation study. Global Environmental Change 23: 144-156.

Giljum, S., M. Bruckner, and A. Martinez. 2015. Material Footprint Assessment in a Global InputOutput Framework. Journal of Industrial Ecology. 19(5): 792-804.

Hoekstra, A. Y. and A. K. Chapagain. 2007. Water footprints of nations: Water use by people as a function of their consumption pattern. Water and Resource Management 21: 35-48.

Hoekstra, A. Y. and M. M. Mekonnen. 2012. The water footprint of humanity. Proceedings of the National Academy of Sciences 109(9): 3232-3237.

Hoekstra, A. Y., M. M. Mekonnen, A. K. Chapagain, R. E. Mathews, and B. D. Richter. 2012. Global Monthly Water Scarcity: Blue Water Footprints versus Blue Water Availability. PLoS ONE 7(2): e32688.

Hubacek, K. and K. Feng. 2016. Comparing apples and oranges: Some confusion about using and interpreting physical trade matrices versus multi-regional input-output analysis. Land use policy 50: 194-201.

Hubacek, K., K. Feng, J. C. Minx, S. Pfister, and N. Zhou. 2014. Teleconnecting consumption to environmental impacts at multiple spatial scales. Journal of Industrial Ecology 18(1): 7-9.

Lenzen, M., D. Moran, K. Kanemoto, and A. Geschke. 2013a. Building EORA: A Global Multi-Region Input-Output Database at High Country and Sector Resolution. Economic Systems Research 25(1): 20-49.

Lenzen, M., D. Moran, A. Bhaduri, K. Kanemoto, M. Bekchanov, A. Geschke, and B. Foran. 2013b. International trade of scarce water. Ecological Economics 94: 78-85.

Lutter, S. and S. Giljum. 2009. EXIOBASE manual. Technical description of the compilation of the database produced in EXIOPOL. Accumulative deliverable from the EXIOPOL project. Available at http://www.feem-project.net/exiopol/.

Lutter, S., M. M. Mekonnen, and C. Raptis. 2013. D3.4 - Updated and improved data on water consumption / use imported into the EXIOBASE in the required sectoral (dis)aggregation. Vienna/Zurich/Twente: 
Lutter, S., S. Giljum, S. Pfister, C. Raptis, C. Mutel, and M. M. Mekonnen. 2014. D8.1 - CREEA Water Case Study Report. Available at www.creea.eu. Vienna/Zurich/Twente:

Mekonnen, M. M. and A. Y. Hoekstra. 2011a. The green, blue and grey water footprint of crops and derived crop products. Hydrol. Earth Syst. Sci. 15(5): 1577-1600.

Mekonnen, M. M. and A. Y. Hoekstra. 2011b. The Water Footprint of Electricity from Hydropower. 51. Delft, the Netherlands: UNESCO-IHE.

Peters, G., S. Davis, and R. Andrew. 2012. A synthesis of carbon in international trade. Biogeosciences 9(8): 3247-3276.

Peters, G., J. C. Minx, C. L. Weber, and O. Edenhofer. 2011. Growth in emission transfers via international trade from 1990 to 2008. Proceedings of the National Academy of Science April 2011.

Pfister, S. and P. Bayer. 2013. Monthly water stress: spatially and temporally explicit consumptive water footprint of global crop production. Journal of cleaner production(0).

Pfister, S., A. Koehler, and S. Hellweg. 2009. Assessing the Environmental Impacts of Freshwater Consumption in LCA. Environmental Science \& Technology 43(11): 4098-4104.

Pfister, S., D. Saner, and A. Koehler. 2011a. The environmental relevance of freshwater consumption in global power production. The International Journal of Life Cycle Assessment 16(6): 580-591.

Pfister, S., P. Bayer, A. Koehler, and S. Hellweg. 2011b. Environmental Impacts of Water Use in Global Crop Production: Hotspots and Trade-Offs with Land Use. Environmental Science \& Technology 45(13): 5761-5768.

Pfister, S., B. Edens, C. Graveland, S. Lutter, C. Mutel, and C. Raptis. 2013. Refine and test SEEAW and relevant water accounting parts of SEEA2012; D3.1 of the CREEA project (EC: FP7). Zurich/Den Haag/Vienna:

Platts, U. P. G. 2012. UDI World Electric Power Plants Data Base.

Ridoutt, B. G. and S. Pfister. 2010. A revised approach to water footprinting to make transparent the impacts of consumption and production on global freshwater scarcity. Global Environmental Change 20(1): 113-120.

Schoer, K., J. Giegrich, J. Kovanda, C. Lauwigi, A. Liebich, S. Buyny, J. Matthias, and S. S. GermanyConsultants. 2012. Conversion of European Product Flows into raw material equivalents. Heidelberg: ifeu.

Steen-Olsen, K., J. Weinzettel, G. Cranston, A. E. Ercin, and E. G. Hertwich. 2012. Carbon, Land, and Water Footprint Accounts for the European Union: Consumption, Production, and Displacements through International Trade. Environmental Science \& Technology 46(20): 10883-10891.

Tukker, A. and E. Dietzenbacher. 2013. Global Multiregional Input-Output Frameworks: An Introduction and Outlook. Economic Systems Research 25(1): 1-19.

Tukker, A., T. Bulavskaya, S. Giljum, A. de Koning, S. Lutter, M. Simas, K. Stadler, and R. Wood. 2014. The Global Resource Footprint of Nations. Carbon, water, land and materials embodied in trade and final consumption. Leiden/Delft/Vienna/Trondheim:

Tukker, A., E. Poliakov, R. Heijungs, T. Hawkins, F. Neuwahl, J. M. Rueda-Cantuche, S. Giljum, S. Moll, J. Oosterhaven, and M. Bouwmeester. 2009. Towards a global multi-regional environmentally extended input-output database. Ecological Economics 68(7): 19281937.

Tukker, A., A. de Koning, R. Wood, T. Hawkins, S. Lutter, J. Acosta, J. M. Rueda Cantuche, M. Bouwmeester, J. Oosterhaven, and T. Drosdowski. 2013. EXIOPOL-Development and 
illustratvie analyses of detailed global MR EE SUT/IOT. Economic Systems Research 25(1): 50-70.

UN Water. 2014. Statistics. Global water withdrawals are projected to increase by some $55 \%$ through 2050. http://www.unwater.org/statistics/statistics-detail/en/c/211820/. Accessed 06.02. 2015.

United Nations. 2012. SEEA-W. System of Environmental-Economic Accounting for Water.: United Nations Statistics Division.

United Nations. 2013. Industrial Commodity Statistics. New York: UNO.

Wiedmann, T., H. Schandl, M. Lenzen, D. Moran, S. Suh, J. West, and K. Kanemoto. 2013. The material footprint of nations. Proceedings of the National Academy of Sciences (PNAS).

Wood, R., K. Stadler, T. Bulavskaya, S. Lutter, S. Giljum, A. de Koning, J. Kuenen, H. Schütz, J. Acosta-Fernández, and A. Usubiaga. 2015. Global Sustainability Accounting-Developing EXIOBASE for Multi-Regional Footprint Analysis. Sustainability 7(1): 138-163.

Yu, Y., K. Hubacek, K. Feng, and D. Guan. 2010. Assessing regional and global water footprints for the UK. Ecological Economics 69(5): 1140-1147.

Zhang, C. and L. D. Anadon. 2014. A multi-regional input-output analysis of domestic virtual water trade and provincial water footprint in China. Ecological Economics 100: 159-172. 